\title{
choer
}

\section{História de vida, tráfico e violência nas periferias de Fortaleza-CE}

João Pedro de Santíago Neto

Doutorando em Sociologia - Universidade Federal do Ceará - UFC

Pesquisador do Laboratório de Estudos da Violência - LEV

joao_santiago_33@yahoo.com.br

https://orcid.org/0000-0001-8052-2869

\section{Tuany Maria Sousa Moura}

Mestre em Políticas Públicas e Sociedade - Universidade Estadual do Ceará - UECE

Professora do Instituto Federal de Ciência e Tecnologia do Pará -

IFPA

tuanymoura@ifpa.edu.br

https://orcid.org/0000-0002-6836-8691

\section{Clodomir Cordeiro de Matos Júnior}

Doutor em Sociologia - Universidade de São Paulo - USP

Professor do Programa de Pós-Graduação em Sociologia - UFMA

clodomir.cordeiro@ufma.br

https://orcid.org/0000-0001-5923-6980

\section{Resumo}

Este artigo tem por objetivo explorar sociologicamente a história de vida e as experiências de Reginaldo - adolescente da periferia cearense que, no período de realização do estudo, se encontrava em uma das instituições que compõem a rede do sistema socioeducativo de Fortaleza-CE - relativas aos processos sociais e às trajetórias individuais de engajamento em atividades ilegais. A partir de uma pesquisa de campo, que envolveu observações etnográficas, aplicação de questionários, entrevistas semiestruturadas e tessitura de fragmentos de uma história de vida, refletimos, sob um ponto de vista qualitativo dos dados levantados, a respeito das situações sociais e pessoais que conduzem os jovens moradores das periferias cearenses ao chamado "mundo do crime" e que os mantêm vinculados e dedicados a coletivos criminais. Sob essa perspectiva, o texto discorre sobre os percalços e conflitos da ascensão e queda de jovens traficantes de drogas na capital cearense, assim como sobre as recentes transformações do arranjo criminal no Estado do Ceará e as possibilidades de construção de trajetórias desvinculadas de um mundo fora da lei no qual muitos de nossos jovens aprendem a se movimentar desde cedo.

Palavras-chave jovem; tráfico; periferia; crime; estado do ceará.

Conhecer: debate entre o público e o privado

2021, Vol. 11, no 27

DOI https://doi.org/10.32335/2238-0426.2021.11.27.5543

Licença Creative Commons Atribuição (CC BY 4.0)

Data de submissão 11 jun 2021

Data de publicação 28 ago 2021 


\title{
Life story, drug trafficking and violence in the outskirts of Fortaleza, Ceará, Brazil
}

\begin{abstract}
This article aims to sociologically explore the life story and experiences of Reginaldo - a teenager from the State of Ceará's outskirts who, within the study period, had been admitted to one of the institutions in the socio-educational system network of Fortaleza, Ceará, Brazil - regarding the social processes and individual participation patterns in illegal activities. Starting from field research, which consisted in ethnographic observation, application of questionnaires, semi-structured interviews, and weaving together fragments of a life story, we have thought through, with a qualitative approach to the data collected, the social and personal situations pushing young residents of Ceará's outskirts to the so-called 'world of crime' and keeping them linked and affiliated with criminal groups. From this perspective, the text discusses the setbacks and conflicts of the rise and fall of young drug traffickers in the Ceará's capital city, as well as the recent changes in the criminal organization of the State of Ceará and the possibilities of building life stories unrelated to the outlaw world in which a large part of our youth learn to move at an early age.
\end{abstract}

Key words youth; drug trafficking; outskirts; crime; state of ceará.

\section{Historia de vida, narcotráfico y violencia en las afueras de Fortaleza, Ceará, Brasil \\ Resumen}

Este artículo tiene como objetivo explorar sociológicamente la historia de vida y las experiencias de Reginaldo - un adolescente de la periferia del Estado de Ceará que, en el período del estudio, había sido admitido en una de las instituciones de la red del sistema socioeducativo de Fortaleza, Ceará, Brasil - acerca de los procesos sociales y los patrones de participación individual en actividades ilícitas. A partir de la investigación de campo, que consistió en observación etnográfica, aplicación de cuestionarios, entrevistas semi-estructuradas y tejido de fragmentos de una historia de vida, hemos reflexionado, con un enfoque cualitativo de los datos recolectados, sobre las situaciones sociales y personales que empujan a los jóvenes residentes de las afueras de Ceará al llamado "mundo del crimen" y que los mantienen vinculados y dedicados a grupos criminales. Desde esta perspectiva, el texto discute los retrocesos y conflictos del ascenso y la caída de jóvenes narcotraficantes en la ciudad capital de Ceará, así como los cambios recientes en la organización criminal del Estado de Ceará y las posibilidades de construir historias de vida ajenas al mundo fuera de la ley en el que gran parte de nuestra juventud aprende a moverse a temprana edad.

Palabras clave juventud; narcotráfico; periferia; crimen; estado de ceará. 


\title{
Histoire de vie, trafic de drogue et violence dans la périphérie de Fortaleza, Ceará, Brésil
}

\begin{abstract}
Résumé
Cet article vise à explorer sociologiquement l'histoire de vie et les expériences de Reginaldo - un adolescent de la périphérie de l'État du Ceará qui, au cours de la période d'étude, avait été admis dans l'une des institutions du réseau du système socio-éducatif de Fortaleza, Ceará, Brésil - concernant les processus sociaux et les modèles de participation individuelle à des activités illégales. A partir d'une recherche de terrain, qui a consisté en observation ethnographique, application de questionnaires, entretiens semi-directifs et tissage de fragments d'une histoire de vie, nous avons réfléchi, avec une approche qualitative sur les données recueillies, sur des situations sociales et personnelles qui poussent les jeunes résidents de la périphérie de Ceará au soi-disant « monde du crime » et qui les maintiennent liés et dévoués aux groupes criminels. Dans cette perspective, le texte aborde les revers et les conflits de l'ascension et de la chute des jeunes trafiquants de drogue dans la capitale du Ceará, ainsi que les changements récents dans l'organisation criminelle de l'État du Ceará et les possibilités de construire des histoires de vie sans rapport avec le monde hors-la-loi dans lequel une grande partie de notre jeunesse apprend à se déplacer à un âge précoce.
\end{abstract}

Mots-clés jeunesse; trafic de drogue; périphérie; criminalité; état du ceará.

\section{Introdução}

O protagonismo de adolescentes em atividades ilegais e conflitos armados tem chamado a atenção da opinião pública, dos acadêmicos e dos gestores públicos locais, que, de maneira incisiva, destacam o papel desses sujeitos tanto como principais autores quanto como principais vítimas dos eventos associados à criminalidade urbana em Fortaleza' nas duas últimas décadas. Observados sob o crivo de um olhar punitivo, os jovens moradores das periferias da capital cearense foram historicamente associados no imaginário local a coletivos que permeiam o processo de construção social (Misse, 2006) da violência e do crime enquanto problema nessa região do país (pichadores, gangues de baile funk, torcidas organizadas e, mais recentemente, facções criminosas). Expostos a inúmeras condições de vulnerabilidade, tais como pobreza, desestruturação familiar e evasão escolar, os jovens dos bairros periféricos de Fortaleza emergem como problema (Coelho, 1987), ofuscando as múltiplas violações de direitos humanos que vivenciam ao longo de suas vidas e de suas trajetórias no chamado "mundo do crime" (Ramalho, 1979).

Diante de tal arranjo, este artigo tem por objetivo explorar sociologicamente a história de vida e as experiências de um jovem traficante de drogas de um bairro da periferia de Fortaleza mediante alguns dos aspectos estruturais e das relações sociais que têm possibilitado o envolvimento de sujeitos com esse perfil em atividades ilegais. A partir

\footnotetext{
1 Segundo dados do Instituto Brasileiro de Geografia e Estatística (IBGE, 2018), Fortaleza (capital do Estado do Ceará) possui 121 bairros, nos quais se distribui uma população estimada, para 2020, em 2.686.612 pessoas. A cidade tem o maior produto interno bruto (PIB) do Nordeste e o 9 maior do Brasil.
} 
da análise da trajetória de vida de Reginaldo², entrevistado em 2016 (quando era interno de um dos principais centros socioeducativos da cidade), buscamos explorar as condições e experiências sociais que possibilitam um maciço engajamento de nossos jovens em coletivos criminais, assim como algumas das expectativas diante da vida fora desses grupos.

Buscando contemplar os objetivos propostos, o texto se divide em 4 partes: a) inicialmente, exploramos o lugar das experiências de carência material, evasão escolar e conflitos familiares na trajetória de iniciação de nosso jovem interlocutor no "mundo do crime"; b) em seguida, refletimos sobre como os graduais processos de envolvimento em atividades ilegais e em coletivos armados se articulam a dimensões econômicas, políticas e sociais que garantem aos jovens moradores de Fortaleza não apenas ganhos econômicos, mas também reconhecimento político e social; c) após essa etapa, analisamos as percepções dos diferentes momentos que permearam a trajetória criminal de nosso jovem interlocutor, destacando as experiências de transição, violência e institucionalização envolvidas nos processos de engajamento de sujeitos com esse perfil em atividades ilegais; e d) por fim, destacamos alguns dos caminhos imaginados por nosso interlocutor, e por muitos de nossos jovens, para a tessitura de uma trajetória de vida longe do "mundo do crime", revelando as possibilidades e dificuldades aventadas em tais processos de desengajamento.

\section{Procedimentos metodológicos}

Concordamos com Bourdieu (2005) quando ele considera que seria em função da elaboração dos objetos de nossas investigações que os métodos de abordagem, as técnicas de pesquisa e o tratamento adotado na análise social se impõem. Sob a perspectiva desse autor, devemos mobilizar as técnicas que, dadas as definições dos objetos, pareçam pertinentes e que, dadas as condições sociais e as práticas de pesquisa, sejam empiricamente manejáveis. Articulados a esse pressuposto e privilegiando um olhar qualitativo sobre nosso objeto, trabalhamos na pesquisa que deu origem a este artigo com base em momentos interligados e complementares.

O primeiro momento da pesquisa, realizada em 2016 e 2017, envolveu análise bibliográfica e documental em torno das questões teóricas e metodológicas pertinentes. Após essa etapa, passamos a acompanhar as experiências diárias dos moradores do bairro Serviluz ${ }^{3}$, especialmente na comunidade do Titãzinho ${ }^{4}$. A aproximação de seus moradores e

2 Buscando preservar a integridade física de nossos interlocutores de pesquisa, seus nomes, assim como o do centro socioeducativo onde se encontravam reclusos, não são aqui revelados $\bigotimes$ todos os nomes que aparecem no texto são fictícios.

3 A Comunidade do Serviluz está localizada no bairro Cais do Porto, zona litorânea da capital cearense.

4 A comunidade do Titãzinho está localizada em uma região do Complexo Portuário do Mucuripe, no bairro Cais do Porto, também conhecida como Serviluz. Encrustada em uma área da orla da capital, o espaço foi historicamente ocupado por pescadores, agricultores e trabalhadores portuários, especialmente estivadores, que ocuparam de maneira intensiva o espaço, sobretudo a partir de 1970, com os processos de migração e a construção de moradias precárias (Aguiar, 2017; Almeida, 1995; Anjos, 1983; Sá, 2010). 
as relações estabelecidas permitiram, como descreve Whyte (2005), que contornássemos "imagens estereotipadas" e "eventos espetaculares" divulgados pela mídia, devolvendo os sujeitos a seus contextos sociais e suas atividades rotineiras. Durante esse período, por cerca de 6 meses, os autores deste artigo estiveram no bairro individualmente ou em duplas, buscando acompanhar as atividades cotidianas dos moradores e identificar traços de sua estrutura social e padrões de interação ${ }^{5}$. Entre períodos mais intensos e outros mais esparsos, estivemos no bairro em 48 ocasiões ao longo dos 2 anos. A pesquisa de campo prosseguiu com a aplicação de 20 questionários com jovens internos de um centro socioeducativo para menores em conflito com a lei no ano de 2016 e a realização de entrevistas ${ }^{6}$ com o interlocutor que inspirou a tessitura da história de vida ${ }^{7}$ que compõe as linhas centrais do texto. Os momentos com nosso interlocutor, 9 ocasiões no total, ocorreram no pátio da instituição onde o jovem era interno, permitindo-nos explorar situações relativas à importância da família e do bairro em sua trajetória, aos processos práticos e subjetivos envolvidos no engajamento dos moradores das periferias cearenses em atividades ligadas ao tráfico de drogas e às possibilidades de projetos e expectativas ligadas ao "mundo do crime" (Ramalho, 1979).

Por meio da história de vida de Reginaldo, jovem morador do Serviluz que tinha 17 anos na época das entrevistas, os dados obtidos durante a etapa de observação no bairro se revelaram sob o crivo das dinâmicas das experiências que cercam os envolvimentos dos jovens moradores das periferias de Fortaleza em coletivos criminais. Mediante uma análise sociológica que busca compreender as múltiplas formas de violação dos direitos humanos com um foco qualitativo, a perspectiva dos jovens envolvidos em práticas ilegais na capital cearense instiga debates sobre a capilaridade das redes criminais estabelecidas na última década nas periferias do Nordeste.

\section{Carências materiais, relações familiares e "envolvimento" com o crime}

Aos 8 anos de idade, Reginaldo, nosso interlocutor, passou a morar com seu avô materno no bairro Serviluz, pois, segundo ele, a situação na casa em que residia com sua mãe em Mucuripe, um bairro vizinho, estava bastante "precária". Filho de um casal que se

5 O registro etnográfico em contextos urbanos nos permite identificar experiências de organização, redes e interações, capazes de qualificarem a compreensão de dimensões microssociais pouco exploradas em olhares "panorâmicos" (Diógenes, 2010).

6 As entrevistas foram caracterizadas por momentos de apresentações polidas, horários previamente acordados, aplicação de um roteiro semiestruturado e uso de gravadores, com a devida autorização de nossos interlocutores.

$7 \quad$ Na introdução à edição de 1966 do clássico de Clifford Shaw, The Jack Roller, Howard Becker considera que a primeira obra a usar a história de vida como técnica de pesquisa na sociologia americana foi The Polish Peasant in Europe and America, de Thomas e Znaniecki, em 1927 (Haguette, 2005). 
separou logo após seu nascimento, Reginaldo considera ter tido uma "vida difícil" desde a infância, atravessada pela carência material e por inúmeros conflitos familiares, sobretudo na relação que construiu com seu pai.

Na comunidade litorânea do Serviluz, Reginaldo se envolveu cedo com a pesca, aprendendo o ofício com seu avô, com quem trabalhou até os 14 anos. Os peixes e frutos do mar apanhados pela dupla na pescaria matinal eram conservados e vendidos durante a noite aos comerciantes do Mercado dos Peixes da Beira-Mar ${ }^{8}$, contribuindo de maneira significativa com a renda da família. Com a voz embargada ao falar sobre seu avô, Reginaldo aponta que aquele foi um período muito feliz em sua vida, com intensos aprendizados sobre o mar e a natureza.

Em seu novo bairro, aos poucos, Reginaldo perdeu contato com seus 2 irmãos mais velhos (um deles tinha 20 e o outro 24 anos de idade na época das entrevistas), que continuaram a viver com sua mãe no Mucuripe após a mudança dele para o Serviluz. Reginaldo considera que teve "bons momentos" com sua família, especialmente os irmãos, os primos e os pais, até o início de sua adolescência. Então, todos se dispersaram por outras periferias de Fortaleza e por cidades no interior do Ceará e em outros estados (como no Rio de Janeiro).

Apesar de morar durante grande parte de sua vida com o avô, Reginaldo considera ter sido bastante próximo da mãe durante a infância e a adolescência, pois, com ela, sempre "bateu bons papos" e "se sentia ouvido". No período em que esteve na casa da mãe e do avô, Reginaldo frequentou regularmente as escolas dos bairros onde morou, tendo concluído a 5 a série do Ensino Fundamental na "idade correta". Indagado sobre sua vida escolar, o jovem considera que, mesmo não tendo "concluído os estudos", possui outras habilidades que "aprendeu com a vida". O conhecimento escolar tem seu peso relativizado quando as experiências da "escola da vida" são colocadas em pauta e passam a permear as narrativas sobre habilidades, sucesso e reconhecimento social. Interpelado sobre as situações que o levaram a parar de estudar, Reginaldo considera que interrompeu sua vida escolar:

\footnotetext{
Porque não tava dando certo. Na escola tinha muitas pessoas que queriam... Eu era pequeno, as pessoas queriam ficar "se fazendo" pro meu lado, me bater. Ai teve um dia que eu me revoltei! Os "caras" que "queria se fazer" pra mim eu pegava uma cadeira ou então saia na mão com eles mesmo! Aí eu peguei e fui expulso! Não quiseram me aceitar lá de volta mais não. (Reginaldo, 17 anos, entrevista realizada em 23/07/2016)
}

\footnotetext{
8 Tradicional ponto turístico da capital cearense, localizado na Avenida Beira Mar, no bairro do Mucuripe. O mercado é localmente conhecido como um lugar para compra e consumo de pescados frescos.
} 
Antes de ser encaminhado à instituição na qual o encontramos, nosso interlocutor afirma que tentou estudar novamente, buscando reunir documentos perdidos para se matricular em uma nova escola, no centro de Fortaleza. Seu pai teria assumido o compromisso de "correr atrás" da instituição para sua matrícula, mas nesse período ele começou a trabalhar de segunda a sexta-feira, tendo de abandonar a "missão" acordada com o filho.

Após abandonar a escola, Reginaldo passou a trabalhar como garçom em um restaurante da capital cearense. Com pouco tempo de serviço, o jovem teria conseguido alugar uma casa e mobiliá-la com a ajuda do pai e do avô. Ele ficou no emprego por cerca de 1 ano, abandonando-o devido ao seu "envolvimento" precoce com o tráfico varejista de drogas no Serviluz. Avaliando retrospectivamente suas escolhas e atitudes, o jovem considera que

[...] não era pra ter desistido. Eu é que vacilei mesmo, peguei e comecei a me envolver junto com os "caras". Negócio de tráfico... Aí eu e meu irmão mais velho acabamos tomando conta de uma parte que meu tio comandava. (Reginaldo, 17 anos, entrevista realizada em 19/09/2016)

A saída precoce da instituição escolar, uma avaliação do trabalho formal a partir dos valores de seus grupos de interesse (Anderson, 2008; Zaluar, 1985) e as experiências vivenciadas em seu círculo familiar são processos que, segundo Reginaldo, o conduziram a um "envolvimento"9 gradual com atividades ilegais no Serviluz. Dificuldades financeiras, conflitos familiares, opções equivocadas e a iniciação paulatina no "mundo do crime" (Ramalho, 1979) se entrelaçam em um arranjo que criou as condições e possibilidades para a entrada de nosso jovem interlocutor nas quadrilhas fragmentadas de traficantes de drogas que àquela altura dominavam a cena criminal da capital cearense.

Reginaldo considera ter sido fácil se envolver no tráfico de drogas, pois seu pai era muito conhecido no bairro em que morava. Hoje com 41 anos, após uma longa carreira criminal e um tiro que quase o matou, ele conseguiu um emprego em uma empresa perto de sua casa e vive "mais tranquilo", já que não se envolvia mais, segundo nosso interlocutor, em qualquer "parada errada" desde que assumiu esse serviço. Mesmo envolvido com atividades ilegais, Reginaldo revela que não era esse o destino que o pai havia planejado para ele, pois no dia em que descobriu seu "envolvimento" com o tráfico ele

9 Termo nativo para descrever, em diferentes níveis de profundidade, os engajamentos dos jovens em atividades ilegais. 
[...] começou a bater em mim e no meu irmão... Ai ele começou a me bater e eu também comecei a brigar, fiquei parado, não! Mas eu fiz errado, era pra eu ter ficado só na minha! Eu pensava assim, "o que ele quer, se ele tava nessa mesma vida, porque eu não posso estar?”. (Reginaldo, 17 anos, entrevista realizada em 23/07/2016)

Além da referência paterna, na época do início de seu "envolvimento", o tio de Reginaldo comandava uma das principais quadrilhas do bairro e arrecadava grandes somas de dinheiro com o tráfico de drogas, encantando o jovem garoto que "trabalhava duro" em troca de "apenas 1 salário mínimo".

A recorrente participação dos familiares de Reginaldo em atividades ligadas ao tráfico de drogas no Serviluz e sua penetração precoce nesse comércio teriam precipitado, segundo seus relatos, a morte de sua mãe e de seu irmão em "atentados"10 perpetrados por grupos rivais. As mortes teriam sido motivadas por rivalidades e disputas pelo domínio dos territórios e pontos de tráfico no interior do bairro, culminando com o sequestro, a tortura e o assassinato de seus familiares. Segundo Reginaldo, sua mãe e seu irmão foram "arrancados de casa", torturados e assassinados, sendo encontrados dias depois em outro bairro da periferia da cidade. Com a voz embargada e os olhos marejados, o silêncio se fez presente quando a mãe de Reginaldo passou a ser o tema principal de sua narrativa. A perda da mãe, como aponta nosso interlocutor, teria sido um gatilho para a decisão de sua "adesão definitiva" ao tráfico, pois depois da morte dela "tudo deixou de fazer sentido" e outras experiências passaram a ser priorizadas em sua trajetória. O "envolvimento" de nossos jovens com o comércio de mercadorias ilegais nas periferias das cidades brasileiras, sob a perspectiva das narrativas e da história de vida de Reginaldo, revela-se um processo gradual que implica dinâmicas familiares, escolares, trabalhistas e comunitárias na construção social do crime e seus roteiros típicos em nosso país (Misse, 2006).

\section{Tráfico de drogas, reconhecimento social e solidariedades periféricas}

Reginaldo recorda que, quando se mudou para o Serviluz, se sentia bastante à vontade em suas ruas e praias, pois, naquele momento, vários de seus familiares se encontravam espalhados pelo interior do bairro. Sua família "era muito respeitada na comunidade", devido ao seu "envolvimento" histórico em atividades ilegais, o que tornou seus primos

\footnotetext{
10 Termo nativo para se referir aos ataques armados, midiaticamente noticiados como "chacinas", contra grupos rivais. Desde o início de 2010, essas práticas se espraiaram pelas periferias de Fortaleza, vitimando centenas de jovens na cidade.
} 
e tios muito conhecidos "nas áreas", especialmente após as prisões e os assassinatos de alguns deles em conflitos de gangues na década de 1990. Narrando as aventuras do início de sua carreira criminal, Reginaldo considerava que "ter nascido onde nasceu facilitou muita coisa!”. Os laços de parentesco, alicerçados por relações de afetividade e fidelidade, permitiram que nosso jovem interlocutor vislumbrasse no tráfico de drogas uma atividade lucrativa e "um meio de vida" capaz de lhe garantir recursos e "consideração" (Sá, 2011).

A trajetória de Reginaldo no tráfico teve início aos 13 anos de idade junto à "firma" de seu tio. Ele e o irmão passaram a atuar como "olheiros" em uma das "bocas" mais lucrativas do Serviluz, muito frequentada por moradores locais e usuários de drogas vindos de outros bairros da cidade. A atuação com o tio permitiu que Reginaldo tivesse acesso à complexa estrutura organizacional e hierárquica do tráfico de drogas em seu bairro e colocou-o em contato com outros jovens, que, assim como ele, foram atraídos pela promessa de ganhos econômicos imediatos (Batista, 1998).

\begin{abstract}
Muitas vezes, o envolvimento é mais por causa da indignação. Às vezes acontece da pessoa ser envolvida e eu não sou. Dou o maior valor a ti e vem outra pessoa e faz alguma coisa contigo ou com tua família!? Aí não dou valor, aí começo a me envolver, a chegar mais perto de tu. Muitas vezes, o cara não é nem envolvido, mas aí vem um "pirangueiro"12 e faz alguma coisa com os amigos ou com alguém inocente que o cara gosta, aí dá aquela indignação e o cara acaba se envolvendo e partindo pra cima. (Reginaldo, 17 anos, entrevista realizada em 19/09/2016)
\end{abstract}

O sentimento de indignação e as experiências de violência contra familiares e amigos ganham significativa relevância quando nosso interlocutor descreve sua iniciação e permanência no "mundo do crime" (Ramalho, 1979) ao longo dos anos. Diante da morte de familiares, tentativas de homicídios contra "parceiros" e amigos, práticas de violência que atingem indiscriminadamente crianças e "inocentes" e baixas expectativas de reconhecimento no "mundo dos playboys", reproduzem-se nas periferias de Fortaleza não apenas os ciclos de vingança que conformam as cenas criminais de nossa cidade, mas também os laços de identificação, pertencimento e lealdade necessários para o funcionamento desse arranjo.

Um conflito no Serviluz emerge na narrativa de Reginaldo como um dos momentos decisivos da manifestação de seu profundo engajamento e lealdade para com as pequenas

\footnotetext{
11 Termo nativo usado para descrever a função daqueles que avisam aos demais integrantes do coletivo que se aproximam grupos rivais ou agentes policiais.

12 Termo nativo, de valor depreciativo, usado para se referir àqueles que praticam atitudes moralmente condenadas no contexto das periferias de Fortaleza. A "pirangagem" engloba comportamentos situacionalmente equivocados, "erros" e "vacilos" que, de alguma maneira, infringem as regras locais de convivência.
} 
quadrilhas de traficantes que se espraiavam pelo bairro. Após saber que um morador havia discutido e agredido um "pivete"13 alguns dias antes, Reginaldo descarregou 11 balas de sua pistola no agressor, levando-o a perder os movimentos das pernas. Nesse perverso ciclo de vingança, nosso interlocutor foi aclamado como um "pivete que se garante", por resolver seus próprios problemas e expulsar "das áreas" um desafeto da quadrilha. Reconhecido como um membro valoroso do coletivo, Reginaldo passou a contar, a partir daquele momento, com os recursos do grupo, que deixou à sua disposição seu apoio financeiro, moral e bélico.

As atividades do tráfico, mediadas pela conexão familiar do pai e do tio com o comércio de drogas ilícitas, assumiram um novo significado quando Reginaldo conheceu os "pivetes" do Titã, pois, então, um ciclo de alianças, proteções, violências, crimes e vinganças ganhou forma e contornos. Se sua entrada no crime foi facilitada pelas relações em seu núcleo familiar, uma nova "família" se forma gradualmente por meio de contatos cotidianos, interações e experiências de liminaridade vivenciadas com seus novos amigos. Fontes de identificações, pertencimentos, solidariedades, reconhecimentos e força, as pequenas quadrilhas de traficantes deixavam em aberto um projeto de vida para seus integrantes (Velho, 1994), ao mesmo tempo que garantiam recursos para ataques e defesas contra grupos rivais.

A garantia da mútua defesa promovida pelos "pivetes" do tráfico era extremamente valorizada na narrativa de Reginaldo, pois o risco da morte era constante em suas experiências cotidianas no Serviluz e no interior da instituição onde cumpria seu período de reclusão. Sob o signo do medo de ataques de grupos rivais e sua possível morte, uma postura de atenção acompanhava nosso interlocutor em todos os lugares que frequentava, seja nos momentos de lazer à beira da praia, seja no caminho rumo à casa de seu avô:

[...] é uma vida de ilusão, a qualquer hora você pode morrer, pode vir um menor do que eu e me matar! Essa vida é assim, é desse jeito... A pessoa pensa assim, tem um bem grandão, aí chega um menorzinho que num dão nada por ele. Ele puxa um bicho (arma) que é maior do que ele e pá, matou! Ai sempre é assim, nunca muda! (Reginaldo, 17 anos, entrevista realizada em 23/07/2016)

A figuração do arranjo criminal que Reginaldo descreve em Fortaleza - o risco de ser apreendido por conta de suas atividades ilegais, o medo da violência praticada por policiais e grupos rivais, a falta de "consideração" de "pivetes" neófitos no "mundo do crime" e a brevidade de uma "vida de ilusão" - revelou para nosso interlocutor a perversidade da

13 Termo de circulação nacional que ganhou nova conotação nas periferias de Fortaleza, passando a se referir de maneira generalizada, sem recorte geracional, aos sujeitos envolvidos em atividades ilegais na capital. 
reprodução das graves violações dos direitos humanos que dizimam as vidas dos jovens moradores das periferias brasileiras.

Laços familiares e o respeito às regras do "mundo do crime" (Ramalho, 1979) colocaram Reginaldo diante de uma difícil decisão quando "um furo" foi deixado na favela por um de seus primos.

\footnotetext{
Muitas vezes o cara dispensa uns "vacilos" só porque é da família... Um dia desses, um primo meu que era da galera daqui começou a se juntar com os "pirangueiros" da Estiva e um dia fez um atentado contra os caras daqui. Aí, né, os elementos daqui viram um dia ele passar de moto... Ai os cara se juntaram e pegaram meu primo de moto, arrastaram ele e apontaram a arma na cabeça dele. Daí ele olhou pra mim e pediu pra eu fazer alguma coisa, mas não pude fazer nada. O cara deu um "vacilo" cruel! (Reginaldo, 17 anos, entrevista realizada em 23/07/2016)
}

O difícil e mortal dilema que Reginaldo enfrentou aponta o fato de que alguns "furos" e erros no círculo dos coletivos criminais, mesmo que cometidos por familiares de seus membros, não podem ser relevados ou minimizados. Expulsões, ataques e assassinatos emergem nesse arranjo como práticas de controle recorrentemente acionadas quando regras, valores e normas são transpostos ou infringidos. Em tais momentos, a "consideração" pelo grupo, sua posição na hierarquia da gangue e sua força bélica exigiram que Reginaldo repensasse sua fidelidade e cumplicidade familiar, revelando a plasticidade dos processos de identificação, pertencimento e reconhecimento nas periferias das grandes cidades nordestinas.

\section{De "pivete" a patrão: tráfico de drogas, coletivos criminais e violência policial}

Iniciando sua trajetória criminal na "firma" do tio, Reginaldo relata que sua posição na hierarquia do coletivo ganhou novos rumos quando passou a trabalhar para um "patrão considerado" do bairro. Ele e seu irmão nutriam uma grande admiração por Caetano e logo foram acolhidos pelo "patrão", que os encarregou de, junto com outros integrantes da pequena quadrilha de traficantes, garantir sua proteção contra possíveis ataques de grupos rivais, que, no período em que se desenrolaram os fatos, travavam uma guerra por territórios e pontos de tráfico no bairro.

Caetano era um "patrão gente boa" e "gostava bastante de falar e ajudar", características que, segundo Reginaldo, fizeram com que ele conquistasse o apoio de muitos 
moradores do Serviluz, especialmente dos adolescentes que estavam iniciando sua carreira criminal. Como aponta nosso interlocutor, se o "pivete" tivesse disposição para traficar ou andar armado, o "patrão chegava junto" para dar o apoio e os insumos necessários para o começo das "pequenas firmas", que se espalhavam pelas ruas e travessas do bairro. Aos poucos, Reginaldo e seu irmão se destacaram como valorosos membros do coletivo e ficaram conhecidos no bairro inteiro por mostrarem coragem e habilidade na condução das atividades do tráfico varejista de drogas. Com a prisão de Caetano, em 2014, nosso jovem interlocutor, fortemente apoiado por familiares e amigos dispostos a "lutar ao seu lado", passou a comandar a chamada "Tropa do Titã"14, ditando os rumos dos fluxos de drogas e armas no local.

Esse período foi marcado por um forte "envolvimento" de Reginaldo em atividades ilegais. O recém-promovido "patrão" lembra que, naquela época, o "verde" e o skunk "estouraram" em Fortaleza, intensificando o fluxo do tráfico de drogas e os ganhos econômicos em vários pontos da cidade. As "balas" apresentavam alterações no preço e na qualidade, promovendo maiores lucros para os comerciantes que naquele momento se envolveram na chegada da nova mercadoria. Nosso interlocutor não recorda ao certo quantos quilos de droga foram comercializados nesse período, contudo, afirma com veemência que foi vendida uma enorme quantidade de mercadorias para os varejistas de seu bairro e de comunidades aliadas.

A "firma" de Reginaldo se concentrou, no início de suas atividades, especialmente no abastecimento de pequenos traficantes varejistas, mas, após a expansão do volume de vendas e do imediato retorno econômico, ele e seu irmão passaram a se aventurar na compra de grandes quantidades de drogas, buscando estabelecer-se no comércio atacadista da capital cearense. Essa foi, segundo Reginaldo, a melhor época da "Galera do Titã", que ganhou notoriedade no bairro e em muitos outros espaços da cidade como um grupo fortemente armado e fornecedor de "drogas de qualidade". A "tropa" lucrou muito com o "adianto" de drogas e fortaleceu-se belicamente, garantindo sua proteção armada contra grupos rivais e meios materiais para a prática de outros crimes, como assaltos a residências.

O controle do comércio de mercadorias ilegais no bairro permitiu que Reginaldo tivesse acesso a uma série de bens de consumo que antes se encontravam fora de seu horizonte de possibilidades. Com um largo sorriso no rosto, Reginaldo recorda que a única medida de liberdade assistida ${ }^{15}$ que teve de cumprir não se refere a atividades ligadas ao

14 Em meados de 2014, um novo arranjo criminal ganhou forma em Fortaleza a partir da mudança da lógica de atuação dos coletivos que, pelo menos desde a década de 1980, atuavam no Estado do Ceará. Essa nova lógica estimulou um processo de capilaridade de coletivos criminais, muitos com atuação nacional e internacional, nas periferias cearenses, alterando significativamente as maneiras de fazer e gerir o crime na capital. A "tropa” é formada por sujeitos locais que, de maneira instável e transitória, mantêm-se ligados aos coletivos de maior expressão e articulação.

15 Para mais detalhes, ver Lei n. 8.069 (Estatuto da Criança e do Adolescente [ECA], 1990). 
tráfico de armas e drogas, mas a uma fuga malsucedida de uma blitz rodoviária em uma área nobre da cidade. Após oito quadras de intensa perseguição em alta velocidade, o carro de Reginaldo teve um pneu furado por um tiro e ele e seu irmão acabaram apreendidos pelos policiais que davam suporte à ação de trânsito.

A apreensão em um centro socioeducativo, assim como a morte, rondava cotidianamente o horizonte de possibilidades de Reginaldo, que compreendia as entrelinhas da lição aprendida nessa fuga malsucedida, ao mesmo tempo que buscava retardar a alta rotatividade que a dinâmica do narcotráfico cobra daqueles que se envolvem em tais atividades. Dinâmicas de assassinatos, internamentos, ascensões e quedas no "mundo do crime", como as que colocaram Reginaldo e seu irmão no poder do narcotráfico local no Serviluz, levavam nosso jovem interlocutor a imaginar todos os dias sua morte ou sua possível saída desse arranjo criminal.

\section{Violência policial, práticas de controle e internamento}

Ao longo de sua vida, a relação de Reginaldo com os agentes armados da lei foi cercada por desconfianças e distanciamentos. Sempre que falava de suas experiências com a força policial, especialmente com a Polícia Militar (PM $)^{16}$, o garoto demonstrava muita indignação e raiva, por considerar suas ações atitudes de "pilantras" e covardes. Nas inúmeras abordagens policiais que sofreu nos anos de "envolvimento" com o crime, o jovem relata ter sido, em inúmeras vezes, alvo de práticas abusivas e violentas por parte dos operadores da lei.

Reginaldo recorda que, após uma abordagem de rua, 6 homens invadiram sua casa sem mandado judicial e reviraram todos os seus móveis e objetos em busca de drogas e armas. Com um ar de enorme satisfação, nosso interlocutor lembra que se sentiu aliviado quando um dos policiais passou a mão em um esconderijo (dentro da parede) e não detectou a presença de drogas. Violências, práticas abusivas e violações de domicílio marcam as experiências e memórias de muitos dos garotos do Serviluz que, não sem indignação, experimentam diariamente a seletividade das forças policiais locais (Coelho, 1987; Pinheiro, 2000).

Articulando as inúmeras experiências que vivenciou a uma série de relatos à qual teve acesso ao longo de sua vida, Reginaldo chega à fatídica conclusão de que na "favela a polícia invade sem nenhum documento, apenas com distintivos!”. Ele relata que:

16 No Brasil, as forças policiais são divididas em 2 corporações com funções relativamente complementares em nível estadual. A Polícia Militar do Estado do Ceará (PMCE) atua ostensivamente nas ruas e a Polícia Civil do Estado do Ceará (PCCE) é responsável pelo registro dos boletins de ocorrência (BO) nas delegacias e pelas respectivas investigações. 
Uma vez eles arrombaram a casa. Eu falei: "não tem nem mandado para entrar na minha casa!". Daí um deles sacou a pistola, colocou na minha cara e disse: "vai falar besteira ainda agora pra ver se não dou um tiro na tua cara?" (Reginaldo, 17 anos, entrevista realizada em 09/08/2016)

Agressões em ruas e vielas, torturas e maus-tratos em centros socioeducativos e desrespeito à garantia da inviolabilidade do lar não são novidades em meio a um arranjo que marginaliza e demoniza os moradores de nossas periferias (Matos, 2008; Santiago, 2008; Zaluar, 1985). Violências, acertos, subornos, conflitos e apreensões permeiam as inúmeras narrativas que buscam retomar as imagens e formas de atuação dos agentes da lei nas periferias de Fortaleza no período em que Reginaldo comandou a "Tropa do Titã".

Violentado e humilhado nas ruas do bairro, a recorrência das práticas violentas por agentes de segurança ganharam um novo capítulo quando as narrativas sobre espancamentos dentro dos centros socioeducativos para jovens em conflito com a lei passaram a ser relatadas. Socos, pontapés, uso de balas de borracha e assassinatos no interior do sistema socioeducativo perpetuam um ciclo de violência e agressões que permeia as múltiplas faces da violação dos direitos humanos por parte das forças de segurança dentro e fora das instituições no país.

Acusado de homicídio, nosso interlocutor afirmou que estava "pagando" por uma ação que não havia praticado ou planejado. Na delegacia, Reginaldo negou sua participação como autor intelectual ou material de crime contra um grupo rival, mas não desvinculou sua execução do espectro de possibilidades das atividades dos integrantes do coletivo ao qual estava vinculado. Encontrado a partir de denúncia dos familiares da vítima e encaminhado a um centro socioeducativo, Reginaldo iniciava então suas aventuras no "colégio pequeno", com enormes possibilidades de um dia chegar ao "colégio grande"17.

Com a internação de Reginaldo, em 2015, a cena criminal no bairro Serviluz encontrou um novo equilíbrio para sua existência e reprodução (Elias, 2001), realocando posições, papéis, hierarquias e valores para garantir o funcionamento das lucrativas atividades que envolvem o tráfico de drogas e armas ilegais em nosso país. Um novo "patrão", ligado momentaneamente a Reginaldo, assumiu seu lugar no "lado de fora", deslocando a centralidade e o protagonismo do nosso interlocutor para o interior de um dos centros socioeducativos mais instáveis da capital cearense.

17 "Colégio pequeno" é um termo nativo que faz referência àquilo que se aprende nas instituições socioeducacionais para onde são enviadas as crianças e os adolescentes em conflito com a lei e "colégio grande" faz alusão às instituições do sistema penal cearense, consideradas "grandes escolas do crime" para os jovens envolvidos em atividades ilegais. 


\section{Perspectivas e sonhos futuros: a vida além do crime}

No centro socioeducativo, durante as entrevistas, Reginaldo alegava reiteradamente sua inocência diante da acusação de homicídio que o conduzira à instituição. Pensativo sobre sua atual condição e tudo que vivera a partir de seu "envolvimento" com o crime, nosso interlocutor expressou certo arrependimento por ter "entrado de cabeça" no tráfico de drogas e nos coletivos criminais dos quais fez parte. O jovem se mostrava extremamente insatisfeito com os rumos que sua vida havia tomado e pretendia mudar de cidade quando ganhasse sua liberdade.

Analisando sua trajetória de maneira retrospectiva, Reginaldo reavaliou a opção de "entrar cedo de cabeça" no tráfico de drogas no Serviluz. Mencionando os nomes dos jovens amigos que perdeu durante sua carreira criminal, nosso interlocutor se considerava um "sobrevivente", pois era um dos poucos de sua geração que, em meio a inúmeros conflitos territoriais e ciclos de vingança, estava prestes a atingir a maioridade legal. Pensativo, Reginaldo pondera que:

\footnotetext{
Se soubesse que ia acontecer isso tudo, eu nem me envolvia, não! Mas o cara num sabe das coisas que vão acontecer, pensa que é o melhor pra ele... Eu pensava assim, os caras tão ganhando, eu também vou ganhar [...] Só que na verdade a guerra é lucrativa e sempre tem aqueles vão morrer pra poder continuar. É tipo uma bola de neve sabe [...] Os cara vão morrendo e ninguém tá nem aí! (Reginaldo, 17 anos, entrevista realizada em 09/08/2016)
}

Diante de um quadro cíclico de conflitos, mortes e sucessões apresentado por Reginaldo, nosso interlocutor nutria a esperança de sair da instituição e retomar, após resolver alguns assuntos inadiáveis, seus estudos e seu trabalho "longe do mundo do tráfico".

Os planos de Reginaldo para o futuro envolviam uma complexa e difícil saída do "mundo do crime" (Ramalho, 1979), viável segundo sua narrativa por meio de uma "mudança radical". Nosso interlocutor pretendia mudar de bairro não apenas devido às carências materiais e de infraestrutura em sua comunidade, mas também em razão da possibilidade de escapar das zonas de influência de familiares e amigos envolvidos em práticas ilegais, sobretudo o tráfico de drogas.

O Serviluz é bom de se morar, eu não queria sair de lá, mas pra eu melhorar de vida eu vou sair! [...] Acho que não dá certo, querer deixar de se "envolver" e voltar para casa, porque a maldade, né, continua no mesmo lugar. Às vezes têm uns e outros 
que voltam e ficam de mansinho, mas depois a galera fica logo sabendo que estava se envolvendo. Eu pretendo parar de vez! (Reginaldo, 17 anos, entrevista realizada em 09/08/2016)

Para Reginaldo, a possibilidade de não se "envolver" significava não só abandonar sua "tropa", seu bairro e seus amigos, mas também reatar relações familiares, deixadas em segundo plano há algum tempo. Sob essa perspectiva, uma das prioridades de nosso interlocutor após sua saída do centro socioeducativo seria visitar seus irmãos - primeiro o que mora em Fortaleza e depois aquele que vive há mais de 10 anos na cidade do Rio de Janeiro. O que the faltava, nesse momento, era sua liberdade, pois, como pontuou, o dinheiro para realizar esses "novos sonhos" estava guardado e era suficiente para sua viagem e estadia em terras fluminenses.

A espiral de conflitos e violências que envolvem os jovens moradores das periferias brasileiras não permitia a Reginaldo imaginar uma "saída fácil" do crime, pois as narrativas sobre supostas "tréguas" que se estabelecem de maneira transitória entre grupos rivais ignoravam haver nesses arranjos "furos que não tem perdão!" Pedindo que nós nos colocássemos em seu lugar, nosso interlocutor ponderou que algumas vezes "cobrar um furo é questão de honra" e que somente o afastamento voluntário do bairro e de seus amigos poderia "livrar sua mente do ódio" e da vontade de vingança que nutria contra aqueles que cruzaram seu caminho.

\footnotetext{
Jamais vou tá tranquilo vendo o inimigo que fez a covardia com minha mãe passar pela frente e eu não poder fazer nada... A intenção dos caras de querer a paz é boa, mas eles não sabem a dor e o ódio de perder uma mãe assim, de forma tão cruel. Eu já sei como é que é, ali esse negócio de paz é um pavio de pólvora que a qualquer hora pode estourar. Por isso que vou só pegar minhas coisas e ir embora para o Rio de Janeiro... Lá, vou poder recomeçar a vida do jeito que eu quero, sossegado! (Reginaldo, 17 anos, entrevista realizada em 09/08/2016)
}

Pensativo, Reginaldo se mostrava ansioso para ganhar sua liberdade e construir um futuro voltado à família e a uma "vida diferente". Embora isso parecesse algo difícil, a narrativa do jovem associava a superação de um passado trágico ao início de uma nova trajetória "sem maldade e violência". 


\section{Considerações finais}

Diante do que buscamos explorar neste artigo, podemos considerar em nossas linhas finais que a história de vida de Reginaldo, marcada por processos que ilustram as trajetórias de muitos jovens das periferias urbanas brasileiras, revela pistas sociológicas fundamentais para a compreensão dos fenômenos agrupados sob a rubrica do crime e da violência juvenil em Fortaleza. Nas narrativas identificamos, além das idiossincrasias de suas experiências singulares, os processos e as relações que criam algumas das condições e possibilidades necessárias para o engajamento dos jovens moradores dos bairros populares nordestinos em atividades ligadas ao tráfico de drogas e a disputas armadas entre coletivos criminais.

A partir dos relatos sobre experiências familiares, desventuras escolares, questões trabalhistas e solidariedades grupais, nosso jovem interlocutor nos conduz à compreensão das inúmeras relações e fenômenos relativos aos processos difusos de adesão gradual e precoce dos moradores desses espaços ao "mundo do crime" (Ramalho, 1979). Socialmente condenados por sua origem, seus gostos musicais e, entre outras situações, suas maneiras de vestir e falar, a violência estrutural de um Estado que se faz presente mediante a força policial parece ofuscar o sofrimento cotidiano e as inúmeras violações de direitos aos quais esses jovens se veem rotineiramente expostos.

Diante dos inúmeros atrativos que atravessam uma vida de precariedade material e privações, muitos jovens como Reginaldo sonham com "dias melhores", nos quais a família, o trabalho e as amizades ganham contornos de um caminho real para a saída, ainda vivo, de um dos coletivos que se capilarizaram nas periferias da capital cearense. Cientes dos riscos das atividades ilegais, mas com a responsabilidade de proteger negócios, amigos e famílias, novas histórias de vida são imaginadas pelos sujeitos com base na compreensão dos processos sociais associados à atração e adesão ao "mundo do crime" - tal percepção deve ser considerada na construção de uma democracia que realmente alcance as periferias brasileiras.

\section{Referências bibliográficas}

Aguiar, D. P. (2017). "Marcado para morrer": moralidades e socialidades das crianças na comunidade do Serviluz (Fortaleza-CE) (Dissertação de Mestrado). Universidade Federal do Ceará, Fortaleza, CE. Almeida, R. (1995). Violência, identidade e processos organizativos: o forró da bala como cenário de análise (Dissertação de Mestrado). Universidade Federal do Ceará, Fortaleza, CE.

Anderson, B. (2008). Comunidades imaginadas. São Paulo, SP: Companhia das Letras.

Anjos, C. V., Júnior. (1983). A serpente domada: um estudo sobre a prostituta de baixo meretrício. Fortaleza, CE: Ed. UFC. 
Batista, V. M. (1998). Difíceis ganhos fáceis: drogas e juventude pobre no Rio de Janeiro. Rio de Janeiro, RJ: Revan.

Bourdieu, P. (2005). O Poder Simbólico. Rio de Janeiro, RJ: Bertrand Brasil.

Coelho, E. C. (1987). A oficina do diabo. In M. P. Coelho (Org.), A oficina do diabo e outros estudos sobre criminalidade (pp. 27-196). Rio de Janeiro, RJ: Record.

Diógenes, G. M. S. (2010). Cartografias da cultura e da violência: gangues, galeras e o movimento Hip Hop. São Paulo, SP: Annablume.

Elias, N. (2001). A sociedade de corte. Rio de Janeiro, RJ: Zahar.

Haguette, T. M. F. (1992). Metodologias qualitativas na Sociologia. Petrópolis, RJ: Vozes.

Instituto Brasileiro de Geografia e Estatística. (2018). Panorama municipal: Fortaleza. Recuperado de https://cidades.ibge.gov.br/brasil/ce/fortaleza/pesquisa/10058/60027

Lei n. 8.069, de 13 de julho de 1990. (1990). Dispõe sobre o Estatuto da Criança e do Adolescente e dá outras providências. Brasília, DF.

Matos Júnior, C. C. (2008). Violência, cidadania e medo: experiências urbanas em Fortaleza

(Dissertação de Mestrado). Universidade Federal do Ceará, Fortaleza, CE.

Misse, M. (2006). Crime e violência no brasil contemporâneo: estudos de sociologia do crime e da violência urbana. Rio de Janeiro, RJ: Lumen Juris.

Pinheiro, P. S. (2000). Introdução: o Estado de direito e os não privilegiados na América Latina. In J. E. Méndez, G. O’Donnell, \& P. S. Pinheiro (Orgs.), Democracia, violência e injustiça: o não estado de direito na América Latina (pp. 11-29). São Paulo, SP: Paz e Terra.

Ramalho, J. R. R. (1979). Mundo do crime: a ordem pelo avesso. São Paulo, SP: Graal.

Sá, L. D. (2010). Guerra, mundão e consideração: uma etnografia das relações sociais no Serviluz (Tese de Doutorado). Universidade Federal do Ceará, Fortaleza, CE.

Sá, L. D. (2011). A condição de 'bichão da favela' e a busca por 'consideração': uma etnografia de jovens armados em favelas à beira-mar. DILEMAS: Revista de Estudos de Conflito e Controle Social, 4(2), 339-355.

Santiago, J. P. (2008). Riscos e perigos: um estudo sobre os conflitos cotidianos dos agenciadores do tráfico de drogas ilícitas (Dissertação de Mestrado). Universidade Federal do Ceará, Fortaleza, CE.

Velho, G. (1994). Projeto e metamorfose: antropologia das sociedades complexas. Rio de Janeiro, RJ: Zahar.

White, W. F. (2005). Sociedade de esquina: estrutura social de uma área urbana pobre e degradada. Rio de Janeiro, RJ: Zahar.

Zaluar, A. (1985). A máquina e a revolta: as organizações populares e o significado da pobreza. São Paulo, SP: Brasiliense. 


\section{Para citar este artigo}

Norma A - ABNT

SANTIAGO NETO, J. P.; MOURA, T. M. S.; MATOS JÚNIOR, C. C. História de vida, tráfico e violência nas periferias de Fortaleza-CE. Conhecer: Debate entre o Público e o Privado, v. 11, n. 27, p. 115-133, 2021.

\section{Norma B - APA}

Santiago, J. P., Neto, Moura, T. M. S., \& Matos, C. C., Júnior. (2021). História de vida, tráfico e violência nas periferias de Fortaleza-CE. Conhecer: Debate entre o Público e o Privado, 11(27), 115-133.

\section{Norma C - Vancouver}

Santiago Neto JP, Moura TMS, Matos Júnior CC. História de vida, tráfico e violência nas periferias de Fortaleza-CE. Conhecer: Debate entre o Público e o Privado [Internet]. 2021 [cited Ago 21, 2021];11(27):115-133.

Availablehttps://revistas.uece.br/index.php/revistaconhecer/article/view/5543 